\title{
MODALITIES OF SOLUTIONS TO THE PROBLEM OF INSURANCE AND DEPOSIT PAYMENT IN THE BANKS OF SERBIA
}

\author{
Radomir Šalić \\ Univerzitet „Sinergija“, Bijeljina, Republika Srpska
}

\section{(C) MESTE NGO}

JEL category: G2, G21, G28

\section{Apstrakt}

Problem propadanja poslovnih banaka u Srbiji je sve izraženiji, a sam takav događaj predstavlja veliku društvenu štetu nastalu, uglavnom, zbog plasmana ogromnih tuđih sredstava, odnosno sredstava deponenata ili poverilaca banaka, koja ne mogu da vrate, zato što ne mogu da ih naplate od onih kojima su ih plasirali, tako da samo osigurani depoziti deponenata uspevaju da se naplate, dok drugi deo ostaje da čeka naplatu iz stečajne mase u potpunosti, delimično ili da se uopšte ne naplati. Njihovu isplatu obezbeđuje Agencija za osiguranje depozita, a ukoliko nije u mogućnosti da ih isplati, te obaveze naknađuje budžet države, jer država je garant isplate takvih obaveza. Razlozi koji su doveli agenciju i državu u situaciju da moraju da pokrivaju njihove obaveze su različiti i uglavnom se svode na: pogrešne poslovne odluke menadžera banaka u pogledu odabira klijenata za plasman, nepoštovanje ili nepostojanje kvalitetnih procedura za dodelu kreditnih sredstava, nepravovremene i površne kontrole regulatora i eksternog revizora, kao i primena novih propisa zasnovanih na međunarodnim bankarskim standardima. Iz svega prethodnog, definicija problema osiguranja $i$ isplate depozita u Srbiji danas bi trebalo da glasi: „Iznalaženje mogućih modaliteta izvora sredstava za rešenje problema osiguranja $i$ isplate depozita u poslovnim bankama Srbije“. Konstatacijom stanja u posmatranom periodu, utvrđeno je da su prihodi Agencije za osiguranje depozita stalno rasli, zato što su rasli depoziti poslovnih banaka, kao i da je imovina agencije i fonda za osiguranje depozita stalno rasla, da bi na kraju 2012. godine usled donesenih „lex specialis“ akata, ostala bez nje. Da se prethodni scenario pokrivanja osiguranih depozita ne bi ponavljao i u budućnosti, potrebno je međusobno usaglasiti i dopuniti postojeće propise u pogledu: uvođenja dodele certifikata o članstvu u osiguranju depozita, smanjenja visine osiguranog depozita, oduzimanja ovlašćenja agenciji o dodeli kredita, onemogućavanje upravnog odbora agencije

Adresa autora:

Radomir Šalić

salic_radomir@yahoo.com da predlaže donošenje novih zakona lex specialis $i$ institucionalizovanje njihove odgovornosti za pričinjene štete agenciji, dostavljanje svih informacija $i$ izveštaja banaka, eksterne revizije i omogućavanje off-site i on-site 
kontrole banaka od strane agencije, izmena Odluke o klasifikaciji bilansne aktive i vanbilansnih pozicija banaka Narodne banke Srbije, dopuna organizacione strukture agencije u delu investiranja na tržištu novca $i$ tržištu kapitala, povećanje prihoda agresivnijom naplatom potraživanja iz vanbilansa agencije $i$ povremenim i privremenim povećavanjem stope premije osiguranih depozita.

Ključne reči: depoziti, osigurani depoziti, deponenti, agencija, fond za osiguranje depozita.

\begin{abstract}
The problem of decline of business banks in Serbia is ever more pronounced, and the very phenomenon represents a major social damage caused, primarily, by introduction of considerable foreign assets, i.e. the assets of deponents or bank creditors, which they are unable to return, because they are unable to collect payment from those they supplied the assets with. This means that only insured deposits can be charged, while the rest is to be charged through bankruptcy estate in full, i part, or not at all. Their payment is secured by the Insurance Deposit Agency, and in case the Agency is unable to make the payment, those obligations are covered from the state budget, because the state is the guarantor of payments of such obligations. The circumstances which have forced the Agency and the state into covering their obligations are various and in general boil down to: bad business decisions by bank managers in relation to the selection of clients; failure to comply with or a complete absence of quality procedures for granting credit funds; undue and superficial controls of the regulator and the external reviser; and an application of new regulations based on international banking standards. Based on the stated facts, the definition of the problem of insurance and deposit payment in Serbia today should be: "Finding sustainable modalities of sources of funds intended for solving the problem of insurance and deposit payment in the banks of Serbia". By ascertaining the circumstances of the given period, it has been established that the revenues of the Deposit Insurance Agency were constantly on the rise, due to the growth of the business banks' deposits. Also, the assets of the Agency and the Deposit Insurance Fund had a constant growth as well; however, at the end of 2012, due to then passed 'lex specialis' acts, the Agency and the Fund were deprived of those assets. In order to prevent the scenario of covering insured deposits from repeating in the future, it is necessary to coordinate and amend the existing regulations in relation to: an introduction of providing a membership certificate for deposit insurance; a decrease of the amount of the insured deposit; a revocation of the Agency's authority concerning credit grants; preventing the steering committee from proposing new 'lex specialis' laws and institutionalizing their responsibility for the damaged they caused to the Agency; making all information and bank reports available; external revisions and enabling of off-site and on-site bank controls by a foreign agency; an amendment to the Decision about the classification of balance assets and offbalance positions of the banks belonging to the National Bank of Serbia; an amendment of the organizational structure of the agency pertaining to investments on the money market and the capital market; a revenue increase through a more aggressive payment collection of demands from the agency's off-balance and a periodical and temporary increase of the rate of insured deposits premiums.
\end{abstract}

Keywords: deposits, insured deposits, deponents, agency, deposit insurance fund.

\section{UVOD}

Ovaj rad je nastao kao rezultat opservacija i istraživanja problema osiguranih depozita u Srbiji. Zapravo, nastao je u cilju pokušaja da se iznađu modeli pravovremene zaštite sredstava deponenata banaka usled sve češćih slučajeva njihovog iznenadnog bankrotstva i likvidacije. Struktura rada sastoji se, od opisa i definicije problema pokrića sredstava deponenta u Srbiji, utvrđivanja konstatacije u pogledu postojećeg stanja $u$ toj oblasti, određivanja granica istraživanja, utvrđivanja ciljeva istraživanja i modela proučavanja problema, te na kraju, od predloga nekoliko mogućih rešenja problema pokrića sredstava deponenata banaka kao i njihovog sprovođenja. 


\section{OPIS PROBLEMA}

Posle sloma četvrte banke po redu u poslednje dve godine u Srbiji, postajemo definitivno svesni da u sektoru bankarstva, nije baš sve u redu i na svom mestu. Kako? Neke banke počinju da iskazuje ogromne gubitke u poslovanju i usled nemogućnosti da očuvaju svoj kapital ni na minimalnom nivou od 10 miliona evra u dinarskoj protiv vrednosti ( (Zakon o bankama, 2005) (Izmene i dopune Zakona o bankama, 2010)) izražen u apsolutnim vrednostima, ili kada u relativnim vrednostima ne mogu da ostvare minimalnu stopu adekvatnosti kapitala ${ }^{1}$ koju zahteva regulator, propadaju, odnosno najčešće odlaze u stečaj, a zatim u likvidaciju. A kada banka doživi stečaj, bez obzira što jedan deo poverilaca (deponenata) uspe da naplati svoje potraživanje, drugi deo poverilaca ostaje da čeka da svoja potraživanja naplati iz stečajne mase u potpunosti, delimično ili ih uopšte ne naplati. Ovaj drugi deo poverilaca trpi ogromnu štetu, jer svojim sredstvima uglavnom ne može da raspolaže kada to želi, a usled te činjenice trpe i svi ostali u lancu reprodukcije, poslovni partneri (dobavljači, banke), zaposleni u kompaniji kao i celo društvo na kraju.

Propadanje banke je dakle, velika društvena šteta nastala plasmanom (potrošnjom) ogromnih tuđih sredstava, odnosno sredstava (depozita ${ }^{2}$ ) svojih deponenata ili sredstava svojih poverilaca koja ne mogu da vrate svojim deponentima, zato što ne mogu da ih naplate od svojih dužnika. Kada je to propadanje brzo i nenadano, u društvu može da nastane stanje depresije pa čak i panike kao stanje suprotno stanju euforije. Inače, kroz istoriju, ciklusi depresije i euforije u bankarstvu su se smenjivali, a naročito od sedamnaestog veka naovamo. „Njihova se dužina približno poklapala sa vremenom koje je ljudima bilo potrebno da zaborave poslednju katastrofu - a to je bilo vreme

\footnotetext{
${ }^{1}$ U Glavi II Odluke Izvršnog odbora NBS o adekvatnost kapitala se kaže, da pokazatelj adekvatnosti kapitala predstavlja odnos kapitala i rizikom ponderisane aktive za kreditni, tržišni i operativni rizik. Taj pokazatelj, banka je dužna da održava na nivou koji nije niži od 12\%. (NBS, Odluka o adekvatnosti kapitala banke, 2011).
}

2 Prema članu 2, tačka 1, Zakona o osiguranju depozita (2005) ,,depozit je dinarsko ili devizno novčano dovoljno da poumiru finansijski geniji jedne generacije i da ih nadomeste novi majstori za koje su lakoverni ljudi mogli verovati, stanovito vreme čak opravdano, da se sve što dotaknu pretvara u suvo zlato" (Galbraith, 1975). Zašto se sve ovo događa? Postoji mnogo faktora koji prouzrokuju ovakva stanja u bankama no, za naše prilike možemo nabrojati samo njih nekoliko. To su: (1) pogrešne poslovne odluke menadžera banaka u pogledu odabira klijenata za plasman sredstava banaka, (2) nepoštovanje ili nepostojanje kvalitetnih procedura za dodelu kreditnih sredstava u tim bankama, (3) nepravovremene kontrole regulatora u bankarstvu i (4) primena novih propisa zasnovanih na međunarodnim bankarskim standardima ${ }^{3}$.

Pogrešne poslovne odluke i nepoštovanje poslovnih procedura su posledice nastale kao rezultat rada menadžera tih banaka, odnosno, $u$ pitanju je tzv. „moralni hazard“ po kojem poslovne banke svojim delovanjem maksimiziraju vlastite koristi na štetu drugih, pri čemu ne snose punu odgovornost i ne odgovaraju za posledice svojih odluka (Kotowitz, 1987). Ukupnim Iošim rezultatima pojedinih banaka doprineo je površan rad nezavisne eksterne kontrole i kontrole osnovnog regulatora države, ali $i$ prihvatanje $i$ primena međunarodnih standarda $u$ našem bankarstvu. Po tim standardima, plasman sredstava i kreditni rizik, svode se pre svega, na kažnjavanje pogrešnih poslovnih odluka menadžera banaka, kroz knjiženje rezervisanja za potencijalne kreditne gubitke ili rashodne strane bilansa uspeha banke. Više pogrešnih odluka menadžera banke u tom smislu, vodi banku direktno u gubitak koji može da bude toliki da banka gubi kapital kojim raspolaže ili deo kapitala koji je ostavlja ispod nivoa koji zahteva regulator. I u jednom i u drugom slučaju, banka gubi dozvolu za rad i potpada pod prinudnu upravu, nakon čega

potraživanje prema banci koje proizlazi iz novčanog depozita, uloga na štednju, bankarskog tekućeg računa ili drugog novčanog računa i na osnovu kog nastaje zakonska ili ugovorna obaveza banke na povraćaj sredstava“.

3 Bazelski sporazum I, II (Bazelski odbor za nadzor banaka, 2004) (Basel Commettee for banking Supervision, 2010). 
u najvećem broju slučajeva sledi stečaj pa i likvidacija banaka.

Prvi deo poverilaca ili deponenata banke svoje potraživanje uglavnom naplaćuje ili treba da naplati od institucije koja osigurava depozite banaka na nivou države, najčešće agencije za osiguranje depozita a na osnovu propisa koji regulišu ovu materiju ${ }^{4}$ proizašlih iz direktiva 94/19/EC i 2009/14/EC Saveta Evropskog parlamenta (EU Directives, 2009). Pomenute direktive jasno nalažu da osiguranje depozita predstavlja ključni aspekt evropskog tržišta, kojim se zahteva da se sve kreditne institucije pridruže institutu osiguranja depozita. Mada Srbija još uvek nije članica Evropske unije, prihvatila je pomenute propise po kojima, osigurane depozite osigurava Agencija za osiguranje depozita Srbije do određene visine osiguranog iznosa za šta garantuje Republika Srbija. U zadnja četiri slučaja stečaja banaka u Srbiji, Agencija za osiguranje depozita revnosno isplaćuje osigurane depozite deponenata tih banaka i stiče se utisak da se te operacije izvode lako i jednostavno. No očigledno je, da je sve upravo suprotno, jer agencija taj posao ne obavlja samostalno i isključivo iz svojih izvora nego uz obilnu pomoć države, odnosno uz ogromnu asistenciju sredstava budžeta države. A to dalje znači, da građani ove zemlje koji čine najveći deo novčanih tokova budžeta, ni krivi ni dužni pokrivaju gubitke banaka, odnosno gubitke menadžera koji su svesno ili nesvesno donosili pogrešne poslovne odluke u pogledu plasmana tih sredstava.

\section{DEFINICIJA ROBLEMA}

Problem su dakle gubici i to ne samo banaka i budžeta države, nego i deponenata, zaposlenih radnika u tim bankama i kompletnog društva na kraju, izazvani visokim nivoom kreiranih NPL (non performing loans) plasmana ili loših kredita iskazanih kroz tzv. kategoriju D klasifikacije ${ }^{5}$

${ }^{4}$ Zakon o osiguranju depozita („Službeni glasniik RS“61/2005, 116/2008 i 91/2010).

${ }^{5}$ Kategorizacija aktive je definisana kroz Odluku o klasifikaciji bilansne aktive i vanbilansnih stavki banke, prema kojoj je predviđeno da je banka dužna da sva potraživanja od dužnika, klasifikuje u kategorije A, B, V, $G, D$, - na osnovu kriterijuma blagovremenosti, odnosno docnje u izmirivanju obaveza tog dužnika prema banci, aktive banaka. Postavlja se dakle pitanje, do kada će ili, hoće li država i dalje moći da interveniše na ovakav način, odnosno ima li uopšte smisla svaka njena dalja intervencija $u$ tom smislu? Ako se dogodi da još neka od banaka posrne i doživi stečaj, hoće li država postupiti na isti način, pokriti dakle tuđe gubitke i pretvoriti se u servis za spašavanje deponenata propalih banaka? No, ako želi da ostane kredibilna i poštuje usvojene propise, moraće da postupi na isti ili sličan način, no hoće li moći, odnosno hoće li u svakom trenutku imati dovoljno finansijskog potencijala da te transakcije izvede, drugo je pitanje. Fond za osiguranje depozita države u ovom trenutku je gotovo prazan, jer su ga iscrpili prethodni stečajevi banaka (Agrobanka AD, Razvojna banka Vojvodine $A D$ i Privredna Banka $A D$ ), a sredstva u budžetu za pokriće tih gubitaka, makar u ovoj godini, već su utrošena. Naravno, nikome nije želja da se u Srbiji u skoroj budućnosti pojave neke nove propale banke, no u svakom slučaju, potrebno je predvideti takav scenario i pokušati naći neka nova rešenja za njegovo predupređenje. Da bi to bilo moguće izvesti, prvi zadatak koji treba postaviti jeste, da se iz prethodnog opisa, izvede definicija problema. Ta definicija, odnosno definisanje problema osiguranja $\mathrm{i}$ isplate depozita u Srbiji danas bi trebalo da glasi: „Iznalaženje mogućih modaliteta izvora sredstava za rešenje problema osiguranja i isplate depozita u poslovnim bankama Srbije“.

\section{KONSTATACIJA STANJA}

Bankarski sektor Srbije je prošao kroz burne promene, koje su se između ostalog, ogledale u likvidacijama, spajanju, pripajanju i osnivanju potpuno novih banaka i on predstavlja najznačajniji i najdinamičniji deo ne samo finansijskog nego i ukupnog privrednog sistema u prethodnom periodu. Utvrditi ili konstatovati stanje u tom sektoru za protekli period nije jednostavan zadatak, no potrebno je usmeriti se

na osnovu procene njegovog finansijskog stanja, odnosno kreditne sposobnosti i na osnovu kvaliteta sredstava obezbeđenja. U kategoriju D se klasifikuju potraživanja sa sumnjivim ili spornim pravnim osnovom i koja su u docnji dužoj od 180 dana, itd. (NBS, Odluka o klasifikaciji bilansne aktive i vanbilansnih stavki banke, 2011). 
na nekoliko reprezentativnih i verodostojnih činjenica i prikazati ih kroz: stanje i kretanje depozita banaka po svim osnovama, te na prihode i kapital Agencije za osiguranje depozita u periodu od 2005. do 2012. godine.

\subsection{Depoziti banaka u periodu od 2005. do 2012. godine}

Svi depoziti pravnih i fizičkih lica nalaze se u poslovnim bankama i predmet su interesovanja, pored klijenata banke i agencije za osiguranje depozita. Zašto? Zato što upravo ti depoziti predstavljaju osnovicu za obračun i uplatu obaveze (premije) banaka prema agenciji ${ }^{6}$. Što su depoziti veći, veća je i obaveza banaka prema agenciji, odnosno veći su prihodi agencije za osiguranje depozita. Naravno, banke se svaki dan bore za veće depozite, jer time povećavaju svoj finansijski potencijal, čime utiču na povećane plasmane i prihode, ali i rizike (naročito kreditni rizik) koji ugrožavaju ne samo banku nego i deponente banke, dakle vlasnike računa ili imaoce finansijskih sredstava u tim bankama. To ugrožavanje se ogleda kroz verovatnoću, da neće moći da naplate svoje plasmane od dužnika i da nakon toga neće moći da izmire obaveze prema deponentima, vlasnicima računa ili vlasnicima salda sredstava na računima u bankama. Zato države, odnosno njihove agencije, osiguravaju depozite, i to ne sve, nego samo depozite do određenog nivoa za koje se obavezuju, da će in u slučaju propadanja banaka, isplatiti. Depoziti banaka u Srbiji, kretali su se uzlaznom putanjom, odnosno sve vreme su rasli, naročito do izbijanja velike svetske ekonomske krize (2007), kao i nakon toga perioda, samo što je rast tada bio umereniji i sporiji (Tabela 1, Grafikon 1). U strukturi pasive ili izvora sredstava banaka, očigledno je da su depoziti činili njen najveći deo i da su se kretali oko $60 \%$ uz $\pm 2,5 \%$ za posmatrani period. Dakle, depoziti su prilično konstantni no, kada je u pitanju struktura depozita, depoziti stanovništva su rasli brže od svih ostalih (privrede i vanprivrede) i pokazali su, da su se povećali gotovo pet puta na kraju u odnosu na početak posmatranog perioda. Takođe su pokazalo, da su depoziti stanovništva, u ukupnoj strukturi depozita, prevladali u odnosu na druge i da su u 2012. godini, dostigli nivo od čak $58,2 \%$.

Tabela 1: Depoziti i njihova struktura u periodu od 2005. do 2012. godine

\begin{tabular}{|c|c|c|c|c|c|c|c|c|}
\hline Opis & $\begin{array}{c}2005 \mathrm{~g} \\
\text { (u } 000.000\end{array}$ & $\begin{array}{l}2006 \\
0 \text { RSD) }\end{array}$ & 2007 & 2008 & 2009 & 2010 & 2011 & 2012 \\
\hline $\begin{array}{ll}\Sigma \text { Depoziti } & \text { (D) }\end{array}$ & 484.683 & 666.290 & 960.143 & 1.024 .707 & 1.301 .234 & 1.504 .761 & 1.526 .097 & 1.698 .527 \\
\hline Stanovništvo(S) & 206.678 & 294.269 & 428.220 & 466.956 & 627.544 & 792.482 & 855.201 & 988.692 \\
\hline Ostali depoziti & 278.005 & 372.021 & 531.923 & 557.751 & 673.690 & 712.279 & 670.896 & 709.835 \\
\hline Rast D u \% & 100 & 137 & 144 & 107 & 127 & 116 & 101 & 111 \\
\hline S/D u \% & 42.6 & 44.2 & 44.6 & 45.6 & 48.2 & 52.6 & 56.0 & 58.2 \\
\hline 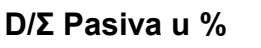 & 62.5 & 57.0 & 61.5 & 57.7 & 60.3 & 59.4 & 57.6 & 59.0 \\
\hline
\end{tabular}

6 Obaveze banaka prema Agenciji za osiguranje depozita su predviđene Članom 7. Zakona o osiguranju depozita koji kaže da radi obezbeđenja sredstava za osiguranje depozita agencija obrazuje fond za osiguranja depozita. Fond za osiguranje depozita obrazuje se od premija za osiguranje depozita koje plaćaju banke itd. Članom 9. istog zakona, predviđeno je da banka plaća premiju za osiguranje depozita na način i u rokovima koje propiše Agencija. Članovima 11, 12 i 13 se kaže da je banka je dužna da plaća početnu premiju, tromesečnu i vanrednu premiju. Početna premija iznosi $0,3 \%$ novčanog dela minimalnog osnivačkog kapitala banke, tromesečnu premija se obračunava i naplaćuje na osnovu prosečnog stanja ukupnih osiguranih depozita u banci u prethodnom tromesečju i iznosi najviše $0,1 \%$ u odnosu na ukupne osigurane depozite banaka, a ako sredstva fonda za osiguranje depozita nisu dovoljna za isplatu osiguranih iznosa, dopunska sredstva obezbeđuju se naplatom vanredne premije, na osnovu odluke Agencije, gde zbir stopa vanrednih premija u toku jedne godine može da iznosi najviše $0,4 \%$. 
Trend rasta depozita stanovništva u ukupnoj strukturi počinje u 2010. godini i traje do danas, što je pokazalo i jasnu nameru banaka, tj. nameru da su mnogo više pažnje posvetile prikupljanju depozita stanovništava nego pravnih lica. Zašto? Zato što su sve dosadašnje analize u bankarstvu u Srbiji pokazale da je stanovništvo, kako u pogledu štednje tako i u pogledu povrata kredita bankama, mnogo pouzdaniji i poželjniji klijent od pravnih lica.

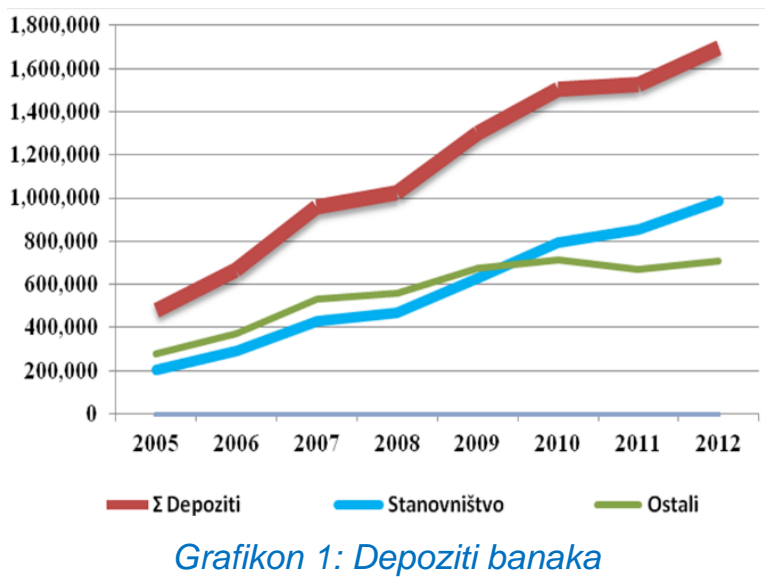

Depoziti stanovništva su konstantniji i dugoročniji od depozita pravnih lica koji, između ostalog, nastaju i kao rezultat obaveznog pologa jednog dela sredstava od strane stanovništava, postavljenog kao uslov za dobijanje kredita. Takvi depoziti se oročavaju, često na period povrata kredita, tako da banke iz tih izvora imaju mogućnost da vrše nove plasmane stanovništvu i na duži period. Na taj način stvaraju uslove (makar u jednom delu) da vode računa o ročnoj usklađenosti svojih sredstava i izvora sredstava, odnosno, poštovanju najstarijeg horizontalnog pravila finansiranja, poznatog kao zlatno bankarsko pravilo finansiranja ${ }^{7}$ koje zahteva da se dugoročno mobilisana sredstva plasiraju dugoročno, a da se kratkoročno mobilisana sredstva plasiraju kratkoročno. No ta činjenica, odnosno takvo ponašanje banaka, stanovništvu može da nanese velike štete ukoliko neka od njih zapadne u stečaj. Veći depoziti (iznad zakonom osiguranih) donose i veće nevolje njihovim deponentima (vlasnicima), jer se teže naplaćuju od banaka, i jer im niko ne garantuje da će moći da ih naplate? Dakle, to su depoziti koji imaju šansu da budu naplaćeni samo ukoliko stečajni upravnik uspe da formira stečajnu masu od naplaćenih potraživanja iz prošlosti, banke koja je u stečaju. No ukoliko se to ne dogodi, poverioci, odnosno deponenti banke mogu da ostanu uskraćeni za svoje depozite, delimično ili u potpunosti, što znači da će pretrpeti odgovarajuće gubitke.

\subsection{Prihodi Agencije za osiguranje depozita}

Agencija za osiguranje depozita Srbije, svoje prihode u posmatranom periodu ostvarivala je po osnovu: provizija i naknada, kamata, naplatom potraživanja iz stečajne mase banaka, donacija, vanrednih prihoda, pozitivnih kursnih razlika ostvarenim na deviznim sredstvima i po osnovu pozitivne razlike između tržišne i knjigovodstvene vrednosti hartija od vrednosti za period u kome je nastala, tako da kumulativno posmatrano, ti prihodi izgledaju (Tabela 2 i Grafikon 2):

Tabela 2: Prihodi i dobit Agencije

\begin{tabular}{lrrrrrrrr}
\hline Opis / godine & $\mathbf{2 0 0 5}$ & $\mathbf{2 0 0 6}$ & $\mathbf{2 0 0 7}$ & $\mathbf{2 0 0 8}$ & $\mathbf{2 0 0 9}$ & $\mathbf{2 0 1 0}$ & $\mathbf{2 0 1 1}$ & $\mathbf{2 0 1 2}$ \\
\hline Prihodi u 1000din & 164.495 & 330.138 & 245.061 & 1.334 .834 & 1.648 .669 & 2.349 .490 & 2.760 .637 & 4.266 .311 \\
Rast prihoda & 100 & 201 & 74 & 545 & 124 & 143 & 117 & 155 \\
Neto dobit & -147.936 & -31.978 & 20.243 & 394.471 & 287.783 & 271.879 & 128.955 & -202.728 \\
Rast dobiti & -100 & -22 & 63 & 1949 & 73 & 94 & 47 & -157 \\
\hline
\end{tabular}

Izvor: (AOD, Finansijski izveštaji, 2006-2012)

\footnotetext{
${ }^{7}$ Razvijanje ovog pravila vezano je za nemačkog autora

Hibnera i delo „Die Banken“ (Huebner, 1854)
} 
Prihodi agencije su evidentni i sve vreme su rasli, osim u 2007. godini kada je prihod u odnosu na prethodnu godinu pao za $26 \%$. Jedan od razloga tog pada je i pojava sistemskog rizika na finansijskim tržištima sveta (SAD, EU) prouzrokovanog padom vrednosti berzanskih indeksa, i shodno tome i padom tržišne vrednosti hartija od vrednosti, tako da Agencija ne samo da nije ostvarila prihod po tom osnovu u toj godini, nego je pretrpela i gubitak od 11,8 miliona dinara na hartijama od vrednosti ${ }^{8}$. Inače, prihodi agencije su u posmatranom periodu višestruko povećani, da bi na kraju 2012. godine, došli na nivo od 4,2 milijarde dinara ili po tadašnjem deviznom kursu na 37,5 miliona evra.

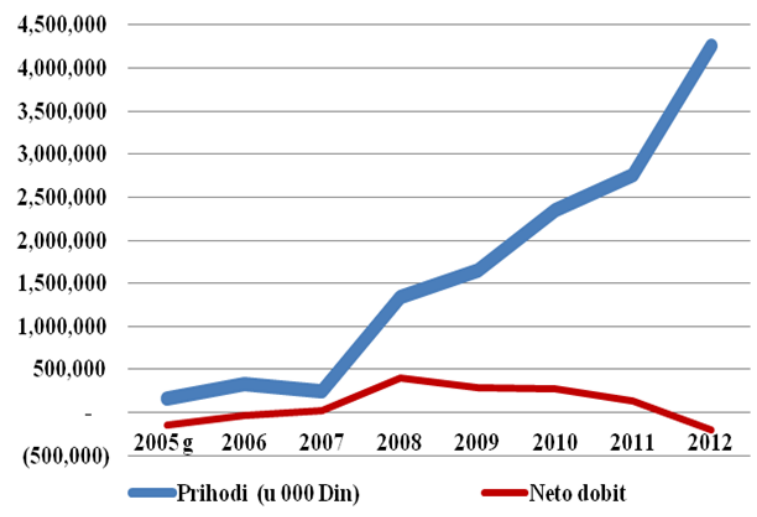

Grafikon 2: Prihodi i dobit agencije

No, i pored višestruko uvećanih prihoda, agencija u određenim periodima (godinama) nije uspela da ostvari i pozitivan rezultat. Zapravo, tabela 2 i grafikon 2 pokazuju, da su se pozitivni i negativni rezultati agencije smenjivali kroz periode. Nivo i intenzitet tih gubitaka bio je veoma različit, od perioda do perioda. Tako su gubici u 2005. bili mnogo viši od gubitaka u 2006, ali su i mnogo niži od gubitaka u 2012. godini.

Prema poslovnim knjigama agencije, početni gubici se objašnjavaju negativnim kursnim razlikama i rashodima nastalim kao posledica pada tržišne vrednosti hartija od vrednosti na finansijskom tržištu. Gubici i veliki rashodi u poslednje dve godine poslovanja su nastali usled knjiženja poslovnih rashoda u iznosu od 241 milion dinara $i$ knjiženja direktnog otpisa po osnovu bespovratne finansijske podrške Banci
Poštanska štedionica u iznosu od 861 milion dinara (AOD, Godišnji finansijski izveštaj za 2012. godinu, 2013).

Ovi rashodi su opteretili prihode agencije i učinili da agencija iskaže ukupan gubitak od 202 miliona dinara. Međutim, ovde nije kraj, jer je agencija iz prethodno kumuliranih sredstava u Fondu za osiguranje depozita, pomenutoj banci doznačila na njen račun mnogo više bespovratnih sredstava od iskazanog gubitka. To je vrednost od 22,7 milijardi dinara ili 199,6 miliona evra prenetih u Banku Poštansku štedionicu kao podrška za preuzimanje isplate sredstava deponentima Agrobanke koja je u međuvremenu doživela stečaj. To su zapravo „ukupna sredstva koja je Agencija imala $u$ svom portfoliju hartija od vrednosti na dan 26.10.2012. godine, preneta na Banku Poštanska štedionica“ (Agencija za osiguranje depozita, 2013). Na taj način Agencija za osiguranje depozita, odnosno njen Fond za osiguranje depozita, ostali su bez kapitala i doveli su u pitanje smisao njenog daljnjeg funkcionisanja.

\subsection{Kapital Agencije za osiguranje depozita}

Zahvaljujući prethodno učinjenim koracima, odnosno direktnom otpisu i velikoj doznaci sredstava u iznosu od cca 200 milona evra, Agencija za osiguranje depozita Beograd, odnosno njen fond za osiguranje depozita je na dan 31.12.2012. godine spao na svega 1,14 milijardi dinara ili cca 10 miliona evra kapitala (Tabela 3 i Grafikon 3). Do tog perioda kapital agencije je rastao, odnosno je ostvarivao je gotovo eksponencijalan rast da bi na kraju posmatranog perioda praktično nestao. Razlog ovakvog stanja u pogledu kapitala agencije, jeste usvajanje i sprovođenja posebnog zakona (Zakon o preuzimanju imovine i obaveza određenih banaka radi očuvanja stabilnosti finansijskog sistema Republike Srbije, 2012), tzv. zakona lex specialis, kojim je, određenim državnim bankama omogućeno da preuzmu druge banke, ili banke u stečaju.

\footnotetext{
${ }^{8}$ Obveznice Republike Nemačke u EUR.
} 
Pomenuti zakon je omogućio da jedna banka preuzme imovinu i obaveze druge banke u kojoj država ima direktno ili indirektno kontrolno učešće, uključujući i banke za posebne namene i banke pod administrativnim upravljanjem. No, nakon sprovođenja transakcije preuzimanja jedne banke od strane druge banke uz pomoć Agencije i sredstava države, Fond za osiguranje depozita je ostao praktično bez kapitala.

Tabela 3: Kapital agencije za osiguranje depozita

\begin{tabular}{llrrrrrrrr}
\hline $\mathrm{Rb}$ & $\begin{array}{l}\text { Opis/godine } \\
\text { (milioni D/E) }\end{array}$ & $\mathbf{2 0 0 5}$ & $\mathbf{2 0 0 6}$ & $\mathbf{2 0 0 7}$ & $\mathbf{2 0 0 8}$ & $\mathbf{2 0 0 9}$ & $\mathbf{2 0 1 0}$ & $\mathbf{2 0 1 1}$ & $\mathbf{2 0 1 2}$ \\
\hline 1 & Kapital - din & 368,2 & $1.222,5$ & $2.531,2$ & $6.280,7$ & $9.633,6$ & $14.136,0$ & $18.262,9$ & $1.141,5$ \\
2 & $\begin{array}{l}\text { Kapital }- \\
\text { EUR }\end{array}$ & 4,3 & 15,47 & 31,94 & 70,88 & 100,47 & 134,00 & 174,5 & 10,0 \\
3 & Index & 100 & 359 & 206 & 222 & 142 & 133 & 130 & 6 \\
4 & Kurs 1/2 & 85.5 & 79 & 79.23 & 88.6 & 95.88 & 105.49 & 104.64 & 113.71 \\
\hline
\end{tabular}

Izvor: (AOD, Finansijski izveštaji, 2006-2012)

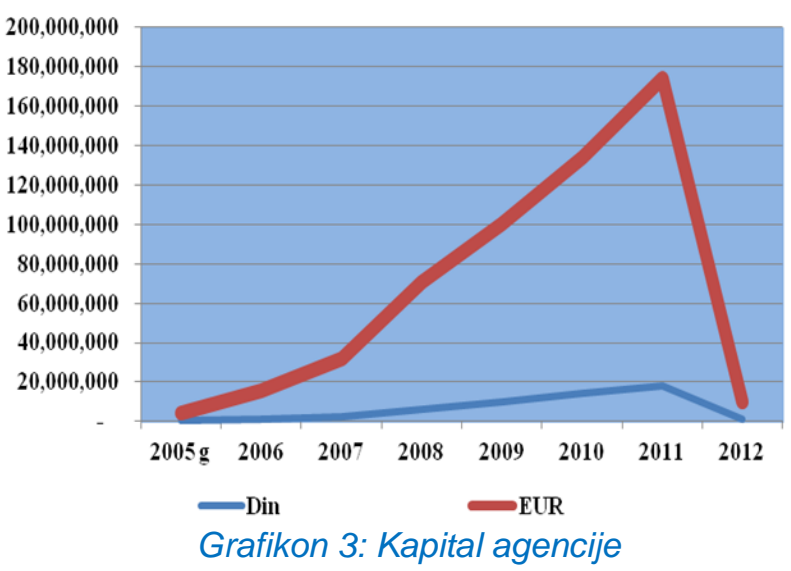

Dakle, depoziti banaka u Srbiji u periodu od 2005. do 2012. godine su rasli, kao što su rasli prihodi i dobit Agencije za osiguranje depozita i Fonda za osiguranje depozita, međutim, primenom samo jednog, posebno usvojenog zakona, sva sredstva kumulirana svih ovih godina su nestala. Fond je ostao bez kapitala, odnosno bez izvora sredstava, a time i bez sredstava. Prema tom zakonu fond je banci koja je preuzela drugu banku, pored značajnog udela države, preneo sav svoj kapital i ostao bez kapitala. Na taj način fond je ugrozio deponente drugih banaka. Kako? Tako što, više ne bi imao odakle, ili ne bi imao dovoljno (kao ni za prethodne stečajeve) sredstava da isplaćuje makar osigurane depozite. Zašto? Pa zato što, niti ima, niti je ikada imao, dovoljno kvalitetnih izvora sredstava za takve isplate. Šta bi se tada dogodilo? Pošto fond ne bi imao odakle da isplaćuje ta sredstva, tu ulogu bi na sebe, kao i do sada, trebalo da preuzme država. Međutim, pitanje je da li država ima više dovoljno izvora za takve isplate i da li država uopšte treba da interveniše po tom osnovu i na takav način.

$\mathrm{Na}$ kraju, osnovno pitanje je, na koji način obezbediti dovoljan nivo kapitala za pokriće osiguranih depozita? Da li finansijski (naročito bankarski) sektor uopšte može da obezbedi zakonom predviđeni nivo sredstava za osiguranje depozita klijenata banaka. Rešenja se moraju naći no, pre toga, potrebno je odrediti cilj ovog istraživačkog rada ali i cilj projekta osiguranja depozita deponenta banaka.

\section{CILJ ISTRAŽIVANJA}

Cilj istraživanja ovog rada i cilj projekta osiguranja depozita je, da Fond za osiguranje depozita obezbedi dovoljno izvora sredstava za pokriće eventualnih budućih isplata osiguranih depozita, uz dva izvedena cilja:

- utvrđivanje modela obezbeđenja izvora sredstava $\mathrm{i}$

- određivanje nivoa depozita koji treba da se osiguraju.

Dakle, ukoliko postoji institucija koja osigurava depozite deponenta banaka, potrebno je da ta institucija, pre svega, obezbedi više modela koji će da omoguće prikupljanje dovoljno kvalitetnih izvora i da razmisli o usklađivanju nivoa osiguranih depozita u skladu sa finansijskim potencijalom bankarskog sistema i potencijalom deponenata. 


\section{PROUČAVANJE PROBLEMA}

U okviru ovog poglavlja, potrebno je analizirati nekoliko segmenata neophodnih za potpunije sagledavanje problema pokrića osiguranih depozita. Ti segmenti bi trebalo da budu:

- analiza nedostataka aktuelnih propisa o osiguranju depozita,

- analiza nedostataka drugih propisa vezanih za rad Agencije za osiguranje depozita,

- analiza rezultata poslovanja Agencije za osiguranje depozita.

\subsection{Analiza nedostataka propisa o osiguranju depozita}

Kada govorimo o propisima o osiguranju depozita tu pre svega mislimo na Zakon o osiguranju depozita, zakonima lex specialis i odlukama Agencije. Aktuelni Zakon o osiguranju depozita Srbije, sadrži sedam poglavlja u kojima razmatra: osnovne odredbe, odredbe o fondu za osiguranje depozita, odredbe o premijama osiguranja, isplatama, izveštajima i kaznenim odredbama. $U$ okviru osnovnih odredaba zakon objašnjava pojedine pojmove iz zakona, te prava i obaveze agencije i banaka, međutim, nigde ne tretira uslove i kriterijume za članstvo banaka u osiguranju depozita. Mnogo uređenije ovakve finansijske institucije u svetu, npr. SAD Federal Deposit Insurance Corporation (FDIC) pa i zemlje u okruženju (BiH, Hrvatska, Slovenija) ovo pitanje tretiraju kroz svoje zakone. Jer, kada postoje postavljeni uslovi bankama za članstvo u osiguranju depozita, podrazumeva se da pored toga što banka ima dozvolu za rad dobijenu od centralne banke, da bi dobila certifikat o članstvu od agencije za osiguranje depozita, mora da ispuni i dodatne kriterijume kao što su npr: potreban kapital, potreban koeficijent likvidnosti, odgovarajući kvalitet aktive, stope profitabilnosti, računovodstvene standarde itd. Zašto bi banke morale da ispunjavaju i ove kriterijume prema agenciji za osiguranje depozita? Prvi razlog je na primer da, pored centralne banke, i agencija za osiguranje depozita mora u svakom trenutku da ima informaciju o visini kapitala svake banke, i da se ne bi događalo da na primer centralna banka mesecima ima informaciju da je kapital neke od banaka daleko ispod novčanog cenzusa (10 miliona evra) ili da joj je stopa adekvatnosti kapitala daleko ispod zakonskog minimuma od $12 \%$, a da agencija za osiguranje depozita ta saznanja ima tek pošto banka izgubi dozvolu za rad $^{9}$. Ili, ako centralna banka ima saznanja da je neka banka nelikvidna, tu informaciju bi na vreme trebalo da podeli i sa agencijom. Zašto? Pa zato što gro problema svake banke koja gubi dozvolu za rad pada na agenciju za osiguranje depozita. Kada se postave ovakvi kriterijumi, agencija za osiguranje depozita može da, za banke koje ih ne ispunjavaju, predvidi isključenje iz njenog članstva. To dalje znači da od momenta isključenja nema ni osiguranja depozita a ni isplata osiguranih depozita, te da novi depoziti koje banka bude primala neće biti osigurani.

$\mathrm{Na}$ ovaj način, agencija bi sačuvala makar deo svog kapitala koji bi dalje mogla da investira u hartije od vrednosti sa fiksnim prihodom $i$ minimalnom ocenom kvaliteta „A“ ili „P 1“ i boljom, ili $u$ ekvivalentu u skladu sa ocenama međunarodno priznate agencije za ocenu hartija od vrednosti. Nije dovoljno samo reći da se „sredstva fonda za osiguranje depozita ulažu na način kojim se umanjuje rizik, održava likvidnost ovog fonda i ostvaruju odgovarajući prihodi“" (član 8 (Zakon o osiguranju depozita, 2005)) i onda ostvarivati negativnu razliku u ceni između tržišne i nabavne ili knjigovodstvene cene hartija od vrednosti (Tabela 4).

Izvor: (AOD, Finansijski izveštaji, 2006-2012)

Tabela 4: Rashodi od promene vrednosti HOV

\begin{tabular}{|l|r|r|r|r|r|r|r|r|r|}
\hline Gubici po HOV & 2005 & 2006 & 2007 & 2008 & 2009 & 2010 & 2011 & 2012 & Ukupno \\
\hline Dinari (000) & & 13.153 & 11.846 & 23.181 & 47.133 & 133.910 & 127.057 & 169.818 & $\mathbf{5 2 6 . 0 9 8}$ \\
\hline EUR & & 166.494 & 149.514 & 261.637 & 491.583 & 1.269 .409 & 1.214 .230 & 1.493 .431 & $\mathbf{5 . 0 4 6 . 2 9 8}$ \\
\hline
\end{tabular}

9 „Prema podacima s kraja juna, koje je Univerzal banka zbog zakonskih odredbi morala da objavi, njena adekvatnost kapitala bila je samo 6,91 odsto." (Vibilia, 2013); "Kapital ove banke je ispod zakonskog minimuma, što je uslovilo ovu neodložnu odluku. Država sada plaća i ceh donetim Zakonom o osiguranim depozitima do 50.000 evra". (Tabaković, 2014) 
Agencija za osiguranje depozita Srbije, je svake godine od njenog osnivanja, gubila na tržištu kapitala i ostvarila je gubitak po tom osnovu ukupno, u iznosu od cca 5 miliona evra. Očigledno je da upravljanje portfoliom hartija od vrednosti nije bilo na zavidnom nivou i da je rezultat, nesnalaženja ili nedovoljnih znanja menadžera agencije iz te oblasti.

Međutim, kada je u pitanju Zakon o osiguranju depozita Srbije, nedostaje i detaljnije obrazloženo poglavlje o izveštavanju. Članom 9 pomenutog zakona navedeno je, da je banka dužna da agenciji dostavlja mesečne izveštaje o ukupnim i osiguranim depozitima i da agencija može da izvrši neposredan uvid u dokumentaciju banke itd. Nigde ne stoji da su banke dužne da sve izveštaje koje dostavljaju centralnoj banci, dostavljaju i agenciji. Zašto bi na primer agencija za osiguranje depozita morala da čeka da je centralna banka izvesti da neka konkretna banka nema ili ima dovoljno kapitala. Ukoliko redovno dobija izveštaje o klasifikaciji aktive i visokim izloženostima banke, agencija može na vreme da odreaguje na određene informacije $\mathrm{i}$ da uoči problem i predloži mere za njegovo prevazilaženje. Inače, takve informacije moraju da budu kvalitetne, a to znači pravovremene, ažurne i tačne, da bi mogle da se upotrebe za donošenje pravilnih poslovnih odluka, koje u našem slučaju mogu da budu i oduzimanje licence za članstvo u osiguranim depozitima, usled čega agencija može da izbegne značajan deo nepotrebnih troškova i sačuva makar deo svog finansijskog potencijala.

Na kraju da pomenemo i Član 7, stav 4, Zakona o osiguranju depozita, u kome se kaže da agencija za osiguranje depozita na osnovu akata vlade može da obezbeđuje finansijsku podršku banci u skladu sa zakonom kojim se uređuje agencija, što je i učinjeno u slučaju Nove Agrobanke. Međutim, član 5 Zakona o bankama (Zakon, 2005) kaže da „niko osim banaka ne može da se bavi davanjem kredita“, što predstavlja kontradiktornost u pogledu nadležnosti propisa. Međutim, pošto je u pitanju poseban zakon potvrđen lex specialis zakonom koji ima prednost i koji je jači u odnosu na opšti zakon, ispada da i agencija za osiguranje depozita može da plasira finansijska sredstva u kredite. Međutim, tu se onda otvaraju dva pitanja koja je potrebno razjasniti.
Prvo pitanje je, da li Agencija za osiguranje depozita u Srbiji zna da radi taj posao? Osim što treba da odobri i izvrši transfer finansijskih sredstava, ona bi trebalo da napravi ocenu kreditne sposobnosti za klijenta kome daje kredit, radi utvrđivanja nivoa kreditnog rizika koji može da joj se dogodi. Da li agencija ume, odnosno da li ima alate kojima može, da na pouzdan način, utvrdi bonitet klijenta. Ako ga ipak poseduje, interesantno bi bilo da se utvrdi, kakvu će odluku da donese ukoliko se ispostavi da taj alat ili sistem pokaže negativan odgovor, odnosno, da pokaže da po svim bankarskim procedurama klijent ne može da dobije kredit koji se zahteva od agencije?

Drugi problem i pitanje na koje je potrebno da se da odgovor jeste, šta je onda sa klasifikacijom aktive? Da li to znači da je i agencija, ako plasira sredstva u kredite, u obavezi da vrši klasifikaciju kredita od kategorije „A“ do kategorije „D“ i da knjiži rezervisanja za potencijalne kreditne gubitke, kao i svaka banka. Ako dakle banka kojoj je agencija dodelila kredit ne izvrši povrat sredstava u ugovorenim rokovima, plasirani kredit mora da se klasifikuje i da se u alikvotnom delu knjiži na rezervisanja za potencijalne kreditne gubitke, tj. na trošak ili rashodnu stranu bilansa uspeha agencije i umanji ukupan finansijski rezultat agencije ili je natera u gubitak. Dakle, ovo su jednostavno nepomirljive relacije, jer su veštački izazvane. Zašto? Zato što nije logično da agencija za osiguranje depozita plasira sredstva bankama (a pogotovo ne bespovratno), jer taj posao rade isključivo banke. Ni u jednom sličnom zakonu o osiguranju depozita, na primer država u okruženju, ne postoji mogućnost plasmana sredstava u kredite klijentima (bankama) agencije. Zašto ovakvu ulogu ima Agencija za osiguranje depozita u Srbiji nije potpuno jasno, no jasno je da se ovakvom njenom ulogom pravi problem tamo gde ne bi trebalo da ga ima?

\subsection{Analiza nedostataka drugih propisa vezanih za Agenciju}

Postoje i propisi koji na indirektan način utiču na aktivnosti i stanje sredstva u agenciji za osiguranje depozita. To su pre svega zakonska i podzakonska akta, kao što su: Zakon o bankama, Zakon o stečaju, Zakon o tržištu kapitala, te odluke centralne banke, na primer, o klasifikaciji 
aktive, o kapitalu, o likvidnosti itd. Odredbe već pomenute Odluke o klasifikaciji aktive banaka (2011) razlikuju se od preporuka međunarodnih direktiva, ali i od odredaba odluka država regiona.

Na primer, odluke o klasifikaciji aktive centralnih banaka Hrvatske i BiH su mnogo podudarnije i zanačajno se razlikuju od odluke Narodne banke Srbije. Zašto je to tako, teško je na ovom mestu dati odgovor, ali je činjenica, da je pomenuta odluka o klasifikaciji aktive u Srbiji, doprinela većem stepenu entropije u pogledu klasifikacije i efekata klasifikacije aktive banaka. Kako? Ako pogledamo Tabelu 5 ovoga rada, lako se uočava da je u odlukama o klasifikaciji aktive Hrvatske i $\mathrm{BiH}$ raspodela procenata rezervisanja za potencijalne kreditne gubitke ravnomernija nego u Srbiji, čiji rasponi su skokovitiji, a što se naročito vidi na primeru kategorije G i D.

Tabela 5: Kategorizacija aktive banaka po državama regiona (Narodne banke Srbije, Hrvatske narodne banke i Centralne banke Bosne i Hercegovine)

\begin{tabular}{|c|c|r|r|r|r|r|r|}
\hline \multicolumn{2}{|c|}{ DRŽAVE } & \multicolumn{2}{c|}{ HRVATSKA } & \multicolumn{2}{c|}{ BIH } & \multicolumn{2}{c|}{ SRBIJA } \\
\hline \multicolumn{2}{|c|}{ KATEGORIJE } & $\begin{array}{c}\text { dani } \\
\text { kašnjenja }\end{array}$ & \multicolumn{1}{c|}{$\begin{array}{c}\text { rezervi } \\
\text { kašnjenja }\end{array}$} & $\begin{array}{c}\text { dani } \\
\text { rezervi }\end{array}$ & $\begin{array}{c}\text { dani } \\
\text { kašnjenja }\end{array}$ & $\begin{array}{c}\% \\
\text { rezervi }\end{array}$ \\
\hline A & A & do 30 & $0 \%$ & do 30 & do 30 & $0 \%$ \\
\hline B & B & (B1) $90-180$ & od $1-30 \%$ & do 90 & od $5-15 \%$ & od $31-60$ & $2 \%$ \\
\hline C & V & (B2) $180-270$ & od $30-70 \%$ & od $90-180$ & od $15-40 \%$ & od $61-90$ & $15 \%$ \\
\hline D & G & (B3) $270-365$ & od $70-100 \%$ & od $180-270$ & od $40-60 \%$ & od $91-180$ & $30 \%$ \\
\hline E & D & C preko 365 & $100 \%$ & preko 270 & $100 \%$ & preko 180 & $100 \%$ \\
\hline
\end{tabular}

Usled te činjenice, bilansna aktiva banaka Srbije ${ }^{10}$ iz kategorije $G$ u kategoriju $D$ prelazi naglo i $u$ velikom rasponu, odnosno, banka mora da doknjiži pored knjiženih 30 , potpuno novih, značajno velikih $70 \%$ rezervisanja za potencijalne kreditne gubitke ili na rashodnu stranu bilansa uspeha banke. To je za svaku banku ogromno opterećenje, jer dolazi naglo i brzo, i često premašuje vrednost tekućeg finansijskog rezultata banke, usled čega se umanjuje i kapital banke. Ako je takvih slučajeva više, banka knjiži (evidentira) sve više rashoda, čime sve više ugrožava svoj kapital i na kraju dolazi u zonu stečaja i likvidacije. Zahvaljujući rigoroznijim odredbama Odluke o klasifikaciji aktive, zona NPL kredita banaka u Srbiji je nepovoljnije strukturirana, od te zone, na primer, u bankama Hrvatske, Bosne i Hercegovine i drugih zemlja Evrope.

\subsection{Analiza rezultata poslovanja agencije}

Tabele 1, 2 i 3 pokazuju finansijske rezultate Agencije za osiguranje depozita Srbije u periodu od 2005. do 2012. godine koji nisu beznačajni, međutim na ovom mestu treba da pokažemo, kojom i kolikom imovinom raspolaže na kraju posmatranog perioda, odnosno na dan 31.12.2012. godine. Za ovu svrhu, poslužićemo se podacima iz objavljenog Godišnjeg finansijskog izveštaja za 2012. godinu Agencije za osiguranje depozita Beograd.

Imovinu ćemo prikazati kroz bilans stanja u skraćenoj verziji (Tabela 6). Imovina Agencije za osiguranje depozita je na kraju 2011. godine iznosila 23,8 milijardi dinara ili 227,8 miliona evra da bi se usled pokrića gubitaka banaka u stečaju, ta imovina na kraju 2012. godine prepolovila $i$ iznosila je 12,6 milijardi dinara ili 111,3 miliona evra.
10 U svom najvećem delu, to su plasmani u kredite koji kasne u otplati i proknjiženi su u aktivi bilansa banke ali i određene pozicije vanbilansa, kao što su izdate garancije i sl. 
Tabela 6: Imovina Agencije za osiguranje depozita na dan 31.12.2012. (AOD, 2013, pp. 5-7)

\begin{tabular}{|c|c|c|c|c|c|}
\hline Opis & 2012 & 2011 & Opis & 2012 & 2011 \\
\hline AKTIVA & \multicolumn{2}{|c|}{ u 000 din } & PASIVA & \multicolumn{2}{|c|}{ u $000 \mathrm{din}$} \\
\hline Gotovina & 384.945 & 593.222 & Kapital & 1.440 .572 & 18.866 .496 \\
\hline Potraživanja & 6.062 .459 & 7.044 .589 & Fond osiguranja depozita & 1.141 .507 & 18.262 .986 \\
\hline Kredit Novoj Agrobanci & 1.137 .183 & & Fond zaštite investitora & 27.238 & \\
\hline Ostali plasmani & - & 2.563 .702 & Ostali kapital & 271.827 & 603.510 \\
\hline Depozit u New York-u & 4.866 .673 & 4.459 .759 & Obaveze & 11.217 .655 & 4.969 .689 \\
\hline Ostala potraživanja & 58.603 & 21.128 & Obaveze prema Banci PŠ & 6.187 .295 & - \\
\hline Osnovna sredstva & 4.879 & 6.277 & Obaveze u stranoj valuti & 5.004 .742 & 4.904 .694 \\
\hline AVR & 18.649 & 15.256 & PVR & 16.317 & 55.331 \\
\hline HOV & - & 16.176 .841 & Ostale obaveze & 9.301 & 9.664 \\
\hline Potraživanja od F BPŠ & 6.187.295 & & & & \\
\hline UKUPNO AKTIVA & 12.658.227 & 23.836 .185 & UKUPNO PASIVA & 12.658.227 & 23.836 .185 \\
\hline $\begin{array}{l}\text { VANBILANSNA } \\
\text { AKTIVA }\end{array}$ & 387.871 .742 & 329.360 .435 & VANBILANSNA PASIVA & 387.871 .742 & 329.360 .435 \\
\hline
\end{tabular}

Agencija je ostala bez kompletnog portfolija hartija od vrednosti i još se zadužila za deo obaveza prema Banci Poštanska štedionica. No, kada se detaljnije sagleda struktura aktive i pasive na kraju 2012. godine, može se videti da je i ta imovina nerealna, zapravo da je gotovo i nema, jer su u aktivi dve najveće pozicije, potraživanja od Fonda za osiguranje depozita u iznosu 6,2 milijarde dinara i položen depozit u banci u New York-u u iznosu od 4,9 milijardi dinara. Iste vrednosti se nalaze $u$ pasivi ili u izvorima sredstava agencije prikazane kao obaveze prema Banci Poštanska štedionica $u$ istom iznosu od 6,2 milijarde dinara $i$ obaveze prema banci u New Yorku u iznosu od cca 5 milijardi dinara, tako da kada se pozicije aktive i pozicije pasive prebiju, ispada da Agencija ima vrlo malo imovine. Ima nešto malo osnovnih sredstava (4,8 miliona dinara) i potraživanje za plasman prema Agro banci $u$ iznosu od 1,1 milijardu dinara plasiranih iz kapitala Fonda za osiguranje depozita Srbije. Međutim, kada se pogleda imovina pomenutog fonda kao podbilansa ukupnog bilansa Agencije za osiguranje depozita Beograd, stanje je kao što je prikazano u tabeli 7 .

Tabela 7: Imovina Fonda za osiguranje depozita na dan 31.12.2012.

\begin{tabular}{|c|c|c|c|c|c|}
\hline Opis & 2012 & 2011 & Opis & 2012 & 2011 \\
\hline AKTIVA & \multicolumn{2}{|c|}{ u $000 \mathrm{din}$} & PASIVA & \multicolumn{2}{|c|}{ u $000 \mathrm{din}$} \\
\hline Gotovina & 4.324 & 40.550 & \multirow{5}{*}{ Kapital } & \multirow{5}{*}{1.141 .507} & \multirow{5}{*}{18.781 .496} \\
\hline Potraživanja & 1.137.183 & 18.740 .543 & & & \\
\hline Kredit Novoj Agrobanci & 1.137 .183 & & & & \\
\hline $\mathrm{HOV}$ & - & 16.176 .841 & & & \\
\hline Oročeni depoziti & & 2.563 .702 & & & \\
\hline UKUPNO AKTIVA & 1.141.507 & 18.781 .093 & UKUPNO PASIVA & 1.141.507 & 18.781 .496 \\
\hline
\end{tabular}


Očigledno je, da na kraju 2012. godine ni Fond za osiguranje depozita nema nikakve imovine. Kako? U aktivi ima kreditni plasman prema Novoj Agrobanci a u pasivi kapital koji ga pokriva, no ukoliko ne uspe da ga naplati (kredit) ili ga ne naplati na vreme, moraće da ga klasifikuje. To znači, da ukoliko ga ne naplati u roku dužem od 180 dana, moraće da ga knjiži na rezervisanja za potencijalne gubitke u 100 procentnom iznosu, a to znači na rashod, čime će ponovo ostati bez kapitala. Međutim, i fond i agencija nastavljaju da rade i prikupljaju prihode po svim osnovama (redovne - premije, kamate i potraživanja iz vanbilansa) tako da je vrlo verovatno da neće izgubiti svu imovinu, no ono što je činjenica, jeste, da su na kraju 2012. godine, ostali gotovo bez imovine, odnosno kako bez sredstava tako i bez izvora sredstava. Međutim, da se kojim slučajem desi da još neka banka Srbije u dogledno vreme ode u stečaj, velika je verovatnoća da ni agencija, a ni fond za osiguranje depozita ne bi mogli da pokriju čak ni osigurane depozite iz njihovih priliva, nego bi to, ponovo bio problem države $i$ moguće isplate tih sredstava isključivo iz budžeta, odnosno iz posebnih ili nenamenskih izvora sredstava budžeta države. No, pitanje je, koliko zapravo ima više smisla da budžet države nastavi da i dalje pokriva gubitke propalih banaka i u najmanju ruku, sumnjivih poslovnih odluka menadžera tih banaka? Da li država ima finansijski potencijal, da pokriva nivo depozita koji je obećala ili za koji se obavezala? Zato je potrebno da i država i agencija sve napore usmere u pravcu iznalaženja drugačijih modela pokrića depozita deponenata banaka.

\section{MOGUĆA REŠENJA PROBLEMA POKRIĆA DEPOZITA}

Zadati cilj ovoga rada glasi: Fond za osiguranje depozita mora da obezbedi dovoljno izvora sredstava za pokriće eventualnih budućih isplata osiguranih depozita. Zašto? Pa valjda zato da bi ispunio svoju osnovnu ulogu, a to je, da zaštiti deponente banaka za makar depozite koji se osiguravaju. Iz prethodnog dela ovoga rada, videlo se da je fond tu svoju ulogu, uz obilatu pomoć države, ispunjavao, no u ovom trenutku postoji veliki stepen neizvesnosti šta će se dešavati u tom smislu u budućnosti, odnosno, hoće li fond imati dovoljno izvora sredstava za te svrhe ili neće? Na primer, u istoriji FDIC-a u USA, nikada nijedan klijent nije izgubio ni jedan cent osiguranih depozita. Nalepnica FDIC-a na svežnjevima novčanica predstavlja simbol poverenja štedišama i štediše koje imaju manje od 250.000 dolara na svojim depozitnim računima, ne moraju da brinu jer su njihova sredstva $u$ potpunosti pokrivena. Isto tako Agencija za osiguranje depozita Srbije i njen Fond za osiguranje depozita jednostavno moraju da iznađu nove modele rešenja ovog problema, a pre svega nove modele iznalaženja izvora sredstava iz mnogo razloga, a pre svega zbog poverenja $u$ bankarski sistem uopšte i zbog ostvarenja kolike tolike sigurnosti za deponente banaka.

I pored ogromne imovine u vanbilansu agencije, očigledno je da se sam proces naplate potraživanja iz tih izvora, odnosno naplate potraživanja iz prošlosti ne odvija lako, nego naprotiv, to je spor proces i da ni ta naplaćena sredstva, makar do sada, nisu bila dovoljna za pokriće svih rashoda koje ostvarila agencija. Zato je potrebno učiniti niz praktičnih koraka, u pravcu povećanja prihoda ili smanjenja rashoda, kako bi se naš cilj ostvario. Jednostavno, ukupan sinergetski efekat svih poteza koje ćemo navesti u narednom delu ovoga rada bi trebao da nam to omogući.

To bi mogli da budu sledeći potezi:

1. Kada su u pitanju propisi, bilo bi potrebno učiniti sledeće:

- Dopuniti Zakon o osiguranju depozita u delu Osnovnih odredaba, odnosno obavezno ugraditi kriterijume agencije, koje bi trebalo da ispune sve banke, i koji bi bili uslov za dobijanje certifikata 0 članstvu u osiguranju depozita. Zašto? Zato da bi se omogućilo agenciji i fondu za osiguranje depozita, da bankama koje te kriterijume ne ispunjavaju u određenom trenutku, oduzmu licencu o članstvu, i na taj način izbegnu nepotrebne troškove ili pokriće depozita;

- Izbaciti iz Zakona o osiguranju depozita određena ovlašćenja agenciji koja joj ne pripadaju niti joj priliče, kao što su dodeljivanje kreditnih sredstava bankama, a naročito bespovratnih. Jer, 
ako agencija nastavi da se bavi ovim poslovima, teško da će ikada kumulirati dovoljno izvora sredstava da bude sigurna da može da pokrije osigurane depozite;

Preformulisati Član 8 Zakona o osiguranju depozita kroz nedvosmisleno izražavanje u koje vrste hartija od vrednosti agencija može investirati i sa kojom minimalnom ocenom kvaliteta ili kojoj ekvivalentnoj oceni mora odgovarati, a u skladu sa ocenama međunarodno priznatih rejting agencija za ocenu hartija od vrednosti,

Sugerisati Narodnoj banci da izmeni Odluku o klasifikaciji bilansne aktive i vanbilansnih pozicija banaka u delu određivanja procenata rezervisanja. Potrebno je dakle, ravnomernije odrediti procente po svakoj kategoriji i utvrditi odgovarajuće raspone između različitih kategorija klasifikacije aktive. Dakle bankama treba da se omogući da, na primer, procenat rezervisanja za kategoriju „V“ aktive, bude od 15 do $30 \%$, a ne samo $15 \%$, ili potpuno preformulisati kategoriju "G“ i dati joj raspon, na primer, minimalno od 50 do $70 \%$ itd. Na taj način će se rasteretiti prilično zbijena klasifikacija aktive i preduprediti iznenađenja i stresovi za sve učesnike u tom procesu, banke, klijente, deponente i na kraju za Agenciju za osiguranje depozita. Zašto agenciji? Zato što kada banka izgubi dozvolu za rad i krene u fazu stečajnog postupka, ubedljivo najviše posla i obaveza ima agencija za osiguranje depozita, i zato je i njoj veoma stalo da se skala klasifikacije koju određuje regulator, preuredi, odnosno kreira prema međunarodnim standardima i po ugledu na druge zemlje, jer se pokazalo da su njihove skale svrsishodnije i povoljnije i za banke i za agencije za osiguranje depozita;

- Preko upravnog odbora agencije pokušati onemogućiti donošenje nekih novih zakona lex specialis u ovoj delatnosti. Jer, veliko je pitanje danas, da li su ti zakoni doneli koristi ili su naneli štete i državi i agenciji. Naravno, vreme će pokazati, no posebno sporne odredbe ovih zakona jesu one, koje daju pravo državi da sa manjinskim paketom akcija $u$ akcionarskom društvu (banci), donosi odluke u ime svih ostalih akcionara o najvažnijim ili sudbinskim pitanjima te institucije. Jednostavno, tu praksu bi trebalo napustiti, jer povodom takvih odluka i država, ali i agencija mogu da budu predmet sudskih sporova na domaćem i međunarodnom nivou;

- Obezbediti da Agencija za osiguranje depozita kao i Narodna banka dobija sve informacije i izveštaje od poslovnih banaka i eksterne revizije, kao i da im se omogući da vrše off-site i on-site kontrolu svih banaka članica agencije. Do danas to niti je bila praksa niti je to bila obaveza banaka. Za agenciju bi bilo veoma korisno kada bi banke bile u obavezi da joj dostavljaju svoje klasifikacije aktive iz kojih bi mogla da ustanovi najveće pojedinačne i grupne izloženosti banaka prema poveriocima, a zatim i opasnosti i negativne posledice koje mogu da uslede. Na primer mogle bi da sa velikim stepenom sigurnosti predvide koji plasmani prelaze iz više u nižu kategoriju, a to znači određena rezervisanja koja banku dovode u gubitak, odnosno u stečaj. Zahvaljujući ovakvim informacijama, agencija bi mogla da preduzima mere za popravljanje situacije u svakoj konkretnoj banci. Ukoliko banka ne bi prihvatila predložene mere, agencija bi takvim bankama oduzimala licencu za članstvo u osiguranju i izbegla nepotrebne troškove;

2. Agencija za osiguranje depozita svakako treba da proširi ili prekomponuje postojeću organizacionu strukturu tako što će kreirati novi sektor, koji će se zvati Sektor za finansijska tržišta sa odeljenjem za tržište kapitala i odeljenjem za tržište novca. Pored toga potrebno je uvesti i radna mesta brokera, investicionog savetnika i portfolio menadžera sa diplomama Komisije za hartije od vrednosti 
Srbije ${ }^{11}$. Zašto? Pa zbog kontinuiranih i velikih gubitaka ostvarenih u prethodnom periodu na tržištu kapitala i tržištu novca i zbog velike vrednosti portfolija hartija od vrednosti kojim je agencija raspolagala (200 miliona evra) $i$ kojim će najverovatnije raspolagati i u budućnosti. Ove poslove moraju da rade vrhunski profesionalci koji će da kreiraju pozitivne razlike $u$ ceni na instrumentima tržišta kapitala i tržišta novca, a ne gubitke koji su obeležili ceo posmatrani period;

3. Da bi Agencija za osiguranje depozita mogla samostalno da isplaćuje osigurane depozite treba da ostvaruje pozitivne finansijske rezultate i da sredstva kumulirana kroz vreme, koristi isključivo za povećanje kapitala fonda za osiguranje depozita. Isto tako sve investicije Fonda moraju da budu u cilju zaštite njegovog kapitala, a ne nepotrebnih pokrića gubitaka propalih banaka. $U$ tom smislu, agencija mora da traži načine kako da poveća svoje prihode ili da smanji svoje rashode. Povećati prihode može da ostvari na dva načina. To su:

- Agresivnija politikom naplate potraživanja iz vanbilansa agencije i

- Povećanje stope premije za osigurane depozite.

Prvi način bi trebalo da je moguć jer je to redovan zadatak agencije za osiguranje depozita čime će se ostvariti poboljšanja koja će da povećaju prihode agencije, no ta prikupljena sredstva treba da se kumuliraju i svrsishodnije troše. To znači da ukoliko se sredstva i budu trošila, da se troše u manjem obimu, a da većina deponenata bude zadovoljna. Da bi to bilo moguće izvesti potrebno je razmisliti o revidiranju postojećeg cenzusa osiguranog depozita. Već sada je više nego očigledno da je nivo novčanog cenzusa od 50.000 evra za pokriće depozita za naše prilike visok i da ga treba svesti na podnošljivu veličinu, odnosno svesti ga na nivo koji predviđa Direktiva 94/19/EC Saveta Evropskog parlamenta (EC, 1994), a to je 20.000 evra. Upoređujući nivo osiguranih sredstava u bankama u okruženju, te ostvarenom nivou depozita po jednom deponentu, predloženi osigurani novčani cenzus po deponentu bi bio sasvim primeren $\mathrm{i}$ odgovarajući, mada je Evropski parlament Direktivom 2009/14 od 11. marta 2009. godine, minimalan osigurani novčani depozit povećao na 50.000 evra, ta odluka ne bi trebalo da bude primenjena sve do definitivnog prijema Srbije u članstvo u Evropskoj Uniji. Zapravo, Agencija za osiguranje depozita bi trebalo da se ponaša u skladu sa trenutnom situacijom u privredi, bankarstvu i društvu uopšte, i da cenzus osiguranih depozita svede na nivo koji je mnogo prihvatljiviji nego današnji. Nije tajna da je i FDIC u SAD svoje osigurane depozite usklađivala sa potrebama vremena u kojem su delovali tako da su nivo od 10.000 dolara po svom aktu iz 1950. godine, usled visoke stope inflacije i negativnih ekonomskih efekata proizašlih nakon rata, u određenom trenutku redukovali na nivo od 5.000 dolara itd. (White, 1999).

Drugi način ili povećanje stope premije osiguranih depozita je moguće izvesti, međutim to nije popularna mera i naići će na nezadovoljstvo poslovnih banaka od kojih se taj prihod ubira. Drugačije rečeno, to predstavlja zapravo, dodatno nametanje gubitaka akcionarima banaka ili dvostruko njihovo preuzimanje odgovornosti, što može izazvati smanjenje kapitala u bankarstvu ( (Esty, 1997); (Wilson \& Kane, 1997)). Inače, već smo pomenuli da smanjenje kapitala nastaje kada neke banke ili deo bankarskog sistema pretrpe gubitke, nakon čega, po pravilu, sledi povećanje premije na osigurane depozite. Banke s manjim kapitalom i lošijim rejtingom imaju više šansi na neuspeh od boljih banaka i na taj način predstavljaju i veću opasnost za agenciju za osiguranje depozita. Poznato je da se regulatori teško odlučuju da povećaju premiju osiguranja, jer za problematične banke to može da znači silazak u nesolventnost, tako da umesto toga, preporučuju im da ojačaju svoje kapitalne pozicije tako što će da smanje rast aktive,

11 Eksperti i stručnjaci sa posedovanjem oficijelne dozvole za rad na ovim poslovima. 
smanje ili ukunu dividendu, i povećaju infuziju eksternog kapitala (FDIC, 1995).

U najboljoj varijanti, povećati stopu premije osiguranja depozita bi trebalo primeniti za samo jedan određeni, ograničeni period, i posmatrati je kao privremenu meru do boljih vremena. Posle tog perioda, tu meru bi trebalo ukinuti i vratiti se na nivo od pre njenog uvođenja. $U$ svetu postoje i slučajevi smanjenja stope premija na depozite, na primer, za banke koje prelaze odgovarajuće nivoe depozita, što prevedeno na naše uslove znači uvođenje diferenciranih stopa premija na depozite, odnosno, stimulisanje rada većih banaka, odnosno banaka sa većim depozitima. Međutim, mnogi analitičari sumnjaju da razlike u premijama mogu tačno da odraze razlike u riziku banaka ili da osiguraju dovoljan razlog za smanjenje moralnog hazarda nekih banaka (Ronn \& Verma, 1986).

4. Povećati odgovornost Upravnog odbora i menadžerske strukture Agencije. Zašto? Zato što in je postojeći zakon abolirao od odgovornosti u pogledu vođenja poslovanja agencije. To je nedopustiva i nelogična odredba neprimerena za bilo koju vrstu institucije. Za sve one koji donose značajnije odluke u pogledu sudbine agencije i fonda za osiguranje depozita, treba da se predvidi moguća odgovornost kao što je to regulisano i u drugim propisima.

\section{ZAKLJUČAK}

Osiguranje depozita poslovnih banka Srbije i isplata tog pokrića sve je izraženija jer je očigledno da ni Agencija za osiguranje depozita a ni Fond za osiguranje depozita u ovom trenutku ne raspolažu sa dovoljnim nivoom izvora finansijskih sredstava za to pokriće. Izveštaji o poslovanju agencije za prethodni period, pokazali su da se ni prihodi ni rashodi agencije nisu ostvarili u željenom obimu i dinamici, niti da agencija $u$ ovom trenutku raspolaže odgovarajućom imovinom. Zapravo, očigledno je da ostvareni prihodi agencije još uvek nisu dovoljni za pokriće rashoda koji postaju sve više nepredvidljivi. Kako? Četiri poslovne banke u Srbiji su u relativno kratkom periodu (poslednje dve godine) propale, odnosno, bankarski sistem i posljedično finansijski sistem zemlje, doživeo je finansijski šok čije su negativne posledice ogromne i evidentne. No, osigurani depoziti tih banaka pokriveni sredstvima fonda za osiguranje depozita i sredstvima budžeta države su isplaćeni, kombinovano, konkretnim deponentima banaka i pripajanjima drugoj banci. Pošto nismo sigurni da su prethodni koraci učinjeni na potpuno adekvatan način i da naše društvo u budućnosti ne bi prošlo kroz slična događanja, bilo bi potrebno međusobno usaglasiti, dopuniti ili izmeniti odgovarajuće propise, a naročito odredbe: Zakona o agenciji za osiguranje depozita, Zakona o osiguranju depozita, Zakona o bankama i Odluke o klasifikaciji bilansne aktive i vanbilansnih pozicija banaka Narodne banke Srbije. Na taj način, stvoreni bi uslovi za sinergijsko delovanje svih učesnika u osiguranju depozita čiji krajnji rezultat bi bio znatno bolji od prethodnog.

\section{Citirani radovi}

AOD. (2006-2012). Finansijski izveštaji. Preuzeto sa Agencija za osiguranje depozita: http://www.aod.rs/o-nama-finansijski.html

AOD. (2013, 02). Godišnji finansijski izveštaj za 2012. godinu. Retrieved from Agencija za osiguranje depozita, Beograd: http://www.aod.rs/pdf/Godisnji_finansijski_izvestaj_za_2012.pdf

Basel Commettee for banking Supervision. (2010). Basel III: International framefwork for liquidity risk measurement, standrads and monitoring. Basel: Bank for International Settlement.

Bazelski odbor za nadzor banaka. (2004). Međunarodni sporazum o mjerenju kapitala i standardima kapitala (Revidirani okvir ed.). Zagreb: Protecon.

EC. (1994, 05 3). Directive 94/19/EC of the European Parliament and of the Council of 30 May 1994 on deposit-guarantee schemes. Official Journal(135), 5-14. Preuzeto sa http://eur- 
lex.europa.eu/legal-

content/EN/ALL/;ELX_SESSIONID=Pr72TkZYGZ2w0s3JLBjY3N4yDgC9TpJnR2pdgVdksFhT W3w8wzFp!1165330594?uri=CELEX:31994L0019

Esty, B. C. (1997). The Impact of Contigent Liability on Commercial Bank Risk Taking. The 33rd Annual Conference on Bank Structure and Competition (str. 402-434). Chicago: Federal Reserve Bank of Chicago.

EU Directives. (2009, 03 13). Directive 94/19/EC on deposit-guarantee shemes as regards the coverage level and the payout delay. Official Journal of the European Union, 5. Preuzeto sa http://ec.europa.eu/internal_market/bank/docs/guarantee/200914_en.pdf

FDIC. (1995). Analysis of Issues Confronting the Savings Association Insurance Fund.

Galbraith, J. K. (1975). Money: Whence it Came, Where it Went. Oxfordshire: HarperCollins Distribution Services.

Huebner, O. (1854). Die Banken. Leipzig.

Kotowitz, Y. (1987). Moral Hazard. U P. Macmillan, The New Palagrave: A Dictionary of Economics. Madison, USA: Macmillan Press Limited.

NBS. (2011, 06 16). Odluka o adekvatnosti kapitala banke. (D. Šoškić, Ur.) Službeni glasnik RS(46; 6/2013; 51/2014), 243.

NBS. (2011, 12 12). Odluka o klasifikaciji bilansne aktive $i$ vanbilansnih stavki banke. Preuzeto sa Narodna banka

Srbije: http://www.nbs.rs/export/sites/default/internet/latinica/20/kpb/klasifikacija_bilansne_aktive.pdf

NBS. (2013, 06 06). Godišnji izveštaj o poslovanju i rezultatima rada NBS 2012. Retrieved from Narodna banka Srbije: http://www.nbs.rs/internet/latinica/90/90_4/godisnji_izvestaj_2012.pdf

Ronn, E. I., \& Verma, A. K. (1986, 09). Pricing Risk-Adjusted Deposit Insurance: An Option-Based Model. Journal of Finance, 41(4), 871-95.

Tabaković, J. (2014, 02 02). Nisam htela novu Agrobanku. (B. Beta, Novinar) Preuzeto sa http://www.b92.net/biz/vesti/srbija.php?yyyy=2014\&mm=02\&dd=02\&nav_id =807180

Vibilia. (2013, 12 08). NBS: Kontrola nad Univerzal bankom. Preuzeto sa Vibilia business portal: http://www.vibilia.rs/vibilia_new.php?page=izvestaj_article\&ID=5330\&lang=sr

White, E. (1999). Deposit insurance. Policy Research Working Paper 1541, 28. doi:10.1596/1813-94501541

Wilson, B. K., \& Kane, E. J. (1997). The Demise of Double Liability as an Optimal Contract for LargeBank Stockholders. 33rd Annual Conference on Bank Structure and Competition (str. 374-389). Chicago: Federal Reserve Bank of Chicago. Preuzeto sa http://www.nber.org/papers/w5848

Zakon. (2005, 07 26). Zakon o agenciji za osiguranje depozita. Sluzhbeni glasnik RS(61; 116/2008; 91/2010), $8 . \quad$ Preuzeto sa http://www.nbs.rs/export/sites/default/internet/latinica/20/zakoni/kpb_agencija_osiguranje_dep ozita.pdf

Zakon. (2005). Zakon o bankama. Službeni glasnik RS(107).

Zakon. (2005). Zakon o osiguranju depozita. Službeni glasnik RS, 61; 116/2008; 91/2010, 7. Preuzeto sa http://www.nbs.rs/export/sites/default/internet/latinica/20/zakoni/kpb_osiguranje_depozita.pdf 
Zakon. (2010). Izmene i dopune Zakona o bankama. Službeni glasnik(91), 61. Preuzeto sa http://www.nbs.rs/export/sites/default/internet/latinica/20/zakoni/kpb_banke.pdf

Zakon. (2012). Zakon o preuzimanju imovine i obaveza određenih banaka radi očuvanja stabilnosti finansijskog sistema Republike Srbije. Službeni glasnik RS, 5. Preuzeto sa http://www.aod.rs/pdf/zakon-o-preuzimanju-imovine-i-obaveza-odredjenih-banaka.pdf

Datum prve prijave:

06.01.2014.

Datum prijema korigovanog rada: $\quad$ 18.06.2014.

Datum prihvatanja članka:

30.06.2014.

\section{Kako citirati ovaj rad?}

Style - APA Sixth Edition

Šalić, R. (2014, 07 15). Modaliteti rešenja problema osiguranja i isplate depozita banaka Srbije. (Z. Čekerevac, Ed.) FBIM Transactions, 2(2), 300-317. doi:10.12709/fbim.02.02.02.30

Style - Chicago Fifteenth Edition:

Šalić, Radomir. 2014. "Modaliteti rešenja problema osiguranja i isplate depozita banaka Srbije." Edited by Zoran Čekerevac. FBIM Transactions (MESTE) 2 (2): 300-317. doi:10.12709/fbim.02.02.02.30.

Style - GOST Name Sort:

Šalić Radomir Modaliteti rešenja problema osiguranja i isplate depozita banaka Srbije [Journal] // FBIM Transactions / ed. Čekerevac Zoran. - Beograd : MESTE, 07 15, 2014. - 2 : Vol. 2. - pp. 300-317.

\section{Style - Harvard Anglia:}

Šalić, R., 2014. Modaliteti rešenja problema osiguranja i isplate depozita banaka Srbije. FBIM Transactions, 15 07, 2(2), pp. 300-317.

Style - ISO 690 Numerical Reference:

Modaliteti rešenja problema osiguranja $i$ isplate depozita banaka Srbije. Šalić, Radomir. [ed.] Zoran Čekerevac. 2, Beograd : MESTE, 07 15, 2014, FBIM Transactions, Vol. 2, pp. 300-317. 